\title{
Urban Disaster Management in Government Communication Perspective
}

\section{Penanggulangan Bencana Perkotaan dalam Perspektif Komunikasi Pemerintahan}

\author{
Jumansyah Jumansyah ${ }^{1 *}$, Anwar Alaydrus², Budiman Budiman³ , Bebika Alamsyah ${ }^{4}$ \\ 1,2,3,4Fakultas Ilmu Sosial dan Ilmu Politik, Universitas Mulawarman
}

OPEN ACCESS

ISSN 2541-2841 (online) ISSN 2302-6790 (print)

Edited by:

Silviana Purwanti

*Correspondence:

Jumansyah

jumansyah@fisip.unmul

$. a c . i d$

Citation:

Jumansyah, Alaydrus A.,

Budiman, Alamsyah, $B$.

(2021)Penanggulangan Bencana Perkotaan dalam Perspektif

Komunikasi Pemerintahan,

Kanal, 9(2).

Doi:10.21070/kanal.v9i2.1057

\begin{abstract}
One indicator of the success of regional governance is the ability of local governments to provide security and comfort for people from natural and social disasters, thus through the authority and resources of the local government they are required to build horizontal and vertical communication in order to respond and provide alternative solutions to all potential disaster that can cause material or non-material loss to the community. Therefore, this study aims to explore disaster management in the perspective of government communication in Botang City. This study used a qualitative case study approach with interactive analysis, so it was found that government communication in Bontang City was built through territorial, program and business approaches. So that the community and the private sector are actively involved in the disaster management process through coordinated communication under the command of the local government. In addition, communication between the local government of Bontang City in disaster management is also continuously improved through active involvement of experts/experts, mass media, and community organizations/NGO/associations.

Keywords: Disaster Management, Government Communication.
\end{abstract}

\begin{abstract}
Abstrak
Salah satu indikator keberhasilan penyelenggaraan pemerintahan di daerah ialah kemampuan pemerintah daerah untuk memberikan kepastian keamanan dan kenyaman masyarakat dari bencana alam dan sosial, dengan demikian melalui otoritas dan sumber daya yang dimiliki pemerintah daerah dituntut membangun komunikasi horizontal maupun vertikal dalam rangka merespon dan memberikan alternatif solutif terhadap segala potensi bencana yang dapat menimbulkan kerugian material maupun non material bagi masyarakat. Untuk itu penelitian ini bertujuan untuk mengeksplorasi penanggulangan bencana dalam perspektif komunikasi pemerintahan di Kota Botang. Penelitian ini menggunakan metode kualitatif dengan pendekatan studi kasus dan analisis data interaktif sampai pada ditemukan sebuah hasil penelitian bahwa komunikasi pemerintahan di Kota Bontang dibangun melalui pendekatan teritorial, program dan bisnis. Sehingga masyarakat dan swasta terlibat
\end{abstract}


aktif dalam proses penanggulangan bencana melalui komunikasi yang terkoordinir di bawah komando pemerintah daerah. Disamping itu komunikasi pemerintah daerah Kota Bontang dalam penanggulangan bencana juga terus ditingkatkan melalui pelibatan aktif dari ahli/pakar, media massa, dan Ormas/LSM/Asosiasi.

Kata Kunci: Penanggulangan Bencana, Komunikasi Pemerintahan.

\section{PENDAHULUAN}

Penanggulangan bencana pada era otonomi daerah oleh sebagian besar daerah belum memiliki kesadaran yang memadai untuk memusatkan pengurangan resiko bencana dalam kebijakan perencanaan pembangunannya, kesulitan dalam pengintegrasian kebijakan karena kompleksitasnya kebijakan yang harus disinergikan (Hidayah dalam Faturahman, 2018). Pandangan tersebut telah mengalami pergesaran secara signifikan, hal tersebut dapat dilihat di daerah tertentu di Indonesia yang telah melakukan transformasi perbaikan penanggulangan bencana ialah Kota Bontang sala satu kota yang terletak di daerah pesisir di Provinsi Kalimantan Timur, dengan potensi bencana yang bervariatif, seperti tsunami, banjir, tanah lonsor, dan puting beliung.

Saat ini Kota Bontang tidak hanya dikenal sebagai kota terbaik di Kalimantan Timur dalam penanggulangan bencana, namun Kota Bontang telah dikenal di tingkat internasional sebagai kota yang memiliki kapasitas penanggulangan bencana yang baik dan bisa menjadi contoh serta rujukan bagi kota-kota di dunia dalam melakukan penanggulangan bencana.

Prestasi yang telah ditorehkan oleh Badan Penanggulangan Bencana Daerah Kota Bontang sukses menjadi instansi BPBD terbaik di Kalimantan Timur. BPBD Bontang menyabet dua penghargaan sekaligus untuk kategori bidang penyelenggaraan pencegahan dan kesiapsiagaan serta kategori bidang penyelenggaraan kedaruratan dan logistik dari BPBD Provinsi Kaltim. Prestasi tersebut bukan hal baru bagi BPBD Kota Bontang, bahkan BPBD Kota Bontang menjadi satu-satunya yang mewakili Indonesia ke Bogota, Brazil pada tahun 2017 untuk berbicara terkait penanggulang bencana. Pemerintah Kota Bontang sebagai aktor utama atas apa yang telah dicapai saat ini yaitu keberhasilan dibidang penanggulangan bencana melalui Badan Penanggulangan Bencana Daerah (BPBD) tentu tidak lepas dari apa yang disebut dengan sinergitas yang pada akhirnya mampu menciptakan kesatuan tindakan antara pemerintah, swasta dan masyarakat dalam penanggulangan bencana di Kota Bontang.

Keterlibatan pihak swasta dan partisipasi masyarakat di Kota Bontang menjadi kekuatan sekaligus peluang bagi Kota Bontang untuk terus melakukan inovasi penanggulangan bencana. Peneliti menyadari bahwa di era modernitas saat ini sala satu kunci keberhasilan pembangunan kota yaitu terletak pada komunikasi yang di bangun oleh pemerintah Kota baik komunikasi vertikal ma- upun horisontal. Kegagalan komunikasi pemerintahan yang dilakukan oleh para pemangku kebijakan, tantu akan sangat beresiko terhadap tujuan-tujuan yang akan dilakukan oleh pemerintah termasuk dalam penanggulangan bencana di perkotaan. Dari berbagai penelitian terkait kebancanaan belum terdapat penelitian yang secara eksplisit membahas fenomena penananggulangan bencana dalam perspektik komunikasi pemerintahan. Beberapa penelitian sebelumnya hanya memfokuskan penelitian penanggulangan kebencanaan dalam konteks kerja sama global, perbaikan manajeman lembaga yang bertanggunga jawab dalam mengatasi resiko bencana, pemilihan alternatif transportasi dalam pendistribusian lagostik di wilayah-wilaya bencana, pemodelan penggunaan Corporate Social Resposibility (CSR) dalam penanggulangan bencana (Erni, 2020; Albris dkk, 2020; Maghfiro dan Hanaoka, 2020; Kanji dan Agrawal, 2020). Untuk itu penelitian ini dianggap memiliki kebaruan tertetu pada wilayah kajiannya dan kedepan panelitian ini diharapkan mampu melahirkan suatu konsep terkait pola-pola atau strategi kominukasi pemeritahan dalam penanggulangan bencana di Kota Bontang yang dapat memberikan kontribusi terhadap keilmuan pemerintahn maupun terhadap penanggulangan bencana bagi pemerintah daerah di Indonesia.

Berdasarkan UU Nomor 24 Tahun 2007 tentang Penanggulangan Bencana, terdapat dua jenis bencana bencana alam adalah bencana yang diakibatkan oleh peristiwa atau serangkaian peristiwa yang disebabkan oleh alam, antara lain: berupa gempa bumi, tsunami, gunung meletus, banjir, kekeringan, angin topan, dan tanah longsor. Bencana sosial adalah bencana yang diakibatkan oleh peristiwa atau serangkaian peristiwa yang diakibatkan oleh manusia, yang meliputi: konflik sosial antarkelompok atau antar komunitas masyarakat, dan teror. Dengan demikian diperlukan upayaupaya yang dapat dilakukan dalam mengurangi dan mengelola resiko bencana.

Salah satu kata kunci yang dapat dipetik dan dipahami dari beberapa pemikiran tersebut ialah bahwa penanggulangan bencana akan berjalan jika diikuti dengan sistem komunikasi yang mapan. Komunikasi pada dasarnya merupakan kemampuan seseorang untuk memproduksi pesan secara tepat. Penjelasan tersebut memberikan sebuah gambaran bahwa dalam komunikasi terdapat pemberi pesan dan penerima pesan. Komunikasi juga dapat dianggap sebagai propses berbagi yang dapat merawat hubungan peserta komunikasi (Kincaid dan Schramm dalam Kamil, 2018). Komunikasi tidak hanya terjadi antara individu, akan tetapi komunikasi bisa terjadi antara kelompok dengan kelompok 
lainnya baik pemerintah maupun swasta. Komunikasi telah menjadi metode utama masyarakat dalam menyampaikan aspirasi kepada pemerintah, begutupun sebaliknya. Menurut Freire (dalam Idris, 2017) komunikasi sebagai proses dialog dan partisipasi, oleh sebab itu segala kepentingan pemerintah sangat dipengaruhi oleh komunikasi yang dilakukan untuk menterjemahkan segala tindakan kebijakan yang telah dipilih. Komunikasi yang baik tentu akan mempengaruhi kesesuaian tindakan dengan rencana yang telah disepakati sebelumnya.

Model komunikasi saat ini harus disikapi positif oleh pemerintah daerah untuk bisa berinovasi untuk meningkatkan performance organisatinmanagement and public serviceimprovement (Noveriyanto dkk, 2018), karena pada hakikatnya pemerintah merupakan sebuah organisasi tertinggi dalam sebuah negara maupun di daerah yang memiliki fungsi untuk melayani masyarakat, melakukan pembangunan dan melakukan pemberdayaan masyarakat serta melakukan perlindungan kepada masyarakat (perlindungan terhadap bencana) secara sustainable. Hal tersebut sejalan dengan seruang UU Nomor 24 Tahun 2007 tentang Penanggulangan Bencana bahwa pemerintah daerah memiliki tanggung jawab yang melekat untuk ikut serta dalam melakukan penanggulangan bencana yang sesuai dengan arah pembangunan yang dilakukan.

Dalam proses komunikasi pemerintahan ada makna atau esensi yang ingin disampaikan oleh komunikator (pemerintah) kepada komunikan (masyarakat dan swasta) yang pada akhirnya dapat menimbulkan kesepahaman atau kesamaan makna terhadap esensi yang dimaksudkan. Untuk mencapai kesepahaman terkait gagasan penanggulangan bencana, dapat diawali dengan suatu kondisi yang kondusif. Karena komunikasi tidak akan terjadi ketika strategi dan taktik berkomunikasi yang dikembangkan oleh komunikator tidak mengarah pada pencarian kesamaan makna atau hanya bersifat sepihak, siapa pun orangnya dan apapun jabatan serta kedudukannya pasti akan mengalami kegagalan pemahaman.

Komunikasi pemeritahan juga dapat dipahami sebagai komunikasi yang dilakukan oleh yang memerintah dengan yang diperintah. Alie (dalam Aminulloh, 2014) menyebutkan bahwa dalam kemunikasi pemerintahan yang buruk tentu akan melahirkan kegagalan pembangunan (penanggulangan bencana) yang direncanakan oleh pemerintah, karena adanya program yang tidak tersampaikan secara utuh. Kemunikasi pemerintahan dianggap memiliki peran central dalam segala kegiatan pemerintah di daerah, karena menyadari bahwa dalam suatau pembangunan sangat diperlukan kerja sama antara semua kelompok kepentingan tanpa merugikan kelompok tertentu.

Sinergitas pemerintah Kota Bontang dengan masyarakat dan swasta melalui komunikasi kontinu menjadi kunci penanggulangan bencana perkotaan yang mampu menggesar paradigma kebencanaan yang dianggap sulit untuk dikelola karena kebijakan tumpang tindih, gografis w- ilayah yang rentan, suku bangsa yang beragam. Namun sebaliknya, pemerintah Kota Bontang telah mampu meminimalisir bencana bahkan telah mampu memaksimalkan konsep mitigasi bencana yang terukur melalui pelibatan partisipasi masyarakat dan swasta serta hal yang terpenting untuk diketahui juga bahwa konsep penanggulangan bencana di Kota Bontang telah memberikan kontribusi terhadap penanggulangan bencana pada tingkat nasional dan internasional.

\section{METODE PENELITIAN}

Penelitian ini dilakukan di Kota Bontang Provinsi Kalimantan Timur. Pada tahun 2020. Metode yang digunakan dalam penelitian ini adalah metode kualitatif dengan pendekatan studi kasus. Dengan pendekatan tersebut peneliti diarahakan untuk mengeksplorasi atau mendalami berbagai bidang, seringa kali peristiwa, program, proses, aktivitas, atau satu individu maupun kelompok dan pada pendekatan ini peneliti mengumpulkan informasi secara lengkap dengan berbagai prosedur pengumpulan data (Creswell, 2019). Metode kualitatif dengan pendekatan studi kasus ini dianggap relevan,karena penelitian yang akan dilakukan berkaitan dengan proses, program-program, aktivitas, dan peristiwa yang berkenaan dengan penanggulangan bencana dalam perspektif komunikasi pemerintahan.

\section{HASIL DAN PEMBAHASAN}

Karekteristik komunikasi pemerintahan dalam penanggulangan bencana di Kota Bontang tidak dapat di dipisahkan dari keberhasilan pemerintah Kota Bontang dalam mewujudkan livable and sustaineble cities. Sistem komunikasi yang dibangun pemerintah Kota Bontang melalui Badan Penanggulangan Bencana Daerah (BPBD) telah menempatkan Kota Bontang sebagai sala satu kota yang mampu mengubah mindset kebancanaan masyarakat dari Keluarga Tangguh Bencana (KATANA) menjadi Manusia Tangguh Bencana (MATANA). Klaim tersebut dibangun atas dasar informasi dan data lapangan peneliti di Kota Bontang.Kepala Pelaksana BPDB Kota Bontang menyampaikn bahwa dalam melakukan penanggulangan bencana kesadaran seluruh pihak dan partisipasi aktif masyarakat mutlak dibutuhkan, untuk mewujudkan hal tersebut maka upaya komunikasi yang dibangun oleh pemerintah Kota Bontang terhadap masyarakat dan swasta menjadi kunci utama.

\section{Komunikasi Pemerintahan Internal dan Eksternal}

Penanggulangan bencana memalalui komunikasi pemerintahan di Kota Bontang tidak hanya di lakukan dengan sistem komunikasi pemerintahan internal (pimpinan ke bawahan) namun juga dilakukan dengan sistem Komunikasi pemerintahan eksternal (Bawahan ke Pimpinan). Dengan sistem komunikasi pemerintahan tersebut maka Organisasi Perangkat Daerah (OPD) di Kota Bontang tidak hanya mene- 
rima dan melaksanakan kebijakan dari pemerintah daerah, namun juga turut memberikan masukan serta evaluasi akan setiap kebijakan atau program yang akan maupun yang telah di lakukan dalam penanggulangan Bencana di Kota Bontang. Dalam upaya mitigasi bencana di Kota Bontang, komuniaksi pemerintahan dilakukan dengan berbagai OPD tidak hanya bertumpu pada BPBD Kota Bontang.Beberapa OPD yang dilibatkan dalam penanggulangan bencana Kota Bontang. Badan Penanggulangan Bencana Daerah (BPBD), Dinas Lingkungan Hidup, Dinas Pekerjaan Umum dan Perumahan Rakyat (Dinas PUPR), Dinas Perumahan,Kawasan Pemukiman dan Pertanahan (Dinas PERKIMTAN), Dinas Penanaman Modal dan Pelayanan Terpadu Satu Pintu (Dinas PMPTSP), Satuan Polisi Pamong Praja (SATPOL PP), Badan Perencanaan, Penelitian, dan Pengembangan (BAPELITBANG) dan kecamatan serta kelurahan.

Dengan komunikasi yang terbangun antara pemerintah internal dan eksternal dalam memaksimalkan penanggulangan bencana. Melalui komunikasi pemerintahan yang terstruktur dengan baik sehingga dapat melahirkan satu kesatuan tindakan antara pemerintah dan beberapa OPD Kota Bontang dalam melakukan mitigasi penanggulangan bencana. Tercatat bahwa angkan kejadian bencana banjir di Kota Bontang dari tahun 2017 sampai tahun 2019 mengalami penurunan yang drastis, dimana pada tahun 2017 terdapat 7 kejadian banjir, tahun 2018 menurun menjadi 3 kejadian banjir dan pada tahun 2019 hanya terdapat 1 kejadian banjir.

Bencana cenderung terjadi pada masyarakat yang rentan. Kerentanan masyarakat diawali dari hati dan perasaan yang belum atau tidak siap menerima fakta adanya bencana. Rasa yang kurang nyaman (cemas) menyebabkan pikiran kacau. Pikiran kacau berdampak pada sikap dan perilaku yang lemah dan kurang berdaya, kurang kompeten dalam mengelola ancaman. Kompetensi dalam mengelola berbagai ancaman dapat lakukan melalui komunikasi (Lestari, 2019). Albris dkk (2020) mengatakan bahwa manajemen resiko bencana dapat dilakukan dengan pencegahan, kesiapan, tanggapan dan pemulihan. Tahapan tersebut dapat dilakukan melalui tata kelola pemerintahan yang baik dengan sistem kalaboratif serta adanya pola komunikasi yang baik agar terjalin intraksi yang kuat antara pemerintah dan semua jenis aktor lainnya (Kanji dan Agrawal, 2020). Salah satu kata kunci yang dapat dipetik dan dipahami dari beberapa pemikiran tersebut ialah bahwa penanggulangan bencana akan berjalan jika diikuti dengan sistem komunikasi yang mapan.

Konsentrasi pemerintah kota bontang dalam memitigasi bencana terletak pada penyediaan posko induk data dan informasi penanggulangan bencana. Inovasi tersebut tercipta atas komunikasi yang dibangun oleh pemerintah bersama dengan OPD terkait. Layanan posko tersebut menyediakan data tunggal berupa kondisi potensi bencana seluruhwilayah kota bontang dilengkapi dengan peta bencana yang akurat dan layanan tersebut dapat diakses oleh seluruh masyarakat baik secara manua maupun virtual. Dengan adanya inovasi layanan kebencanaan tersebut pemerintah kota bontang telah mampu menekan angka kejadian bencana dengan signifikan. Sebagai upaya komitmen dan konsistensi BPBD Kota Bontang dalam penanggulangan bencana tidak hanya sampai pada penyediaan posko induk data dan iformasi bencana di Kota Bontang. Namun BPBD Kota Bontang telah membentukan dan menurunkan tim monitoring bencana hingga tingkat RT (Rukun Tetangga) untuk mengidentifikasi wilayah-wilayah rawan bencana, yang nantinya hasil indentifikasi wilayah rawan bencana tersebut dilaporkan ke RT dan kelurahan secara berkala sebagai bahan mengantisipasi bencana. Dengan demikian komunikasi pemerintahan yang berjalan sampai pada level terendah pemerintahan yang kemudian menembah kemudahan masyarakat dalam mengekses informasi dan mempersiapkan diri dari segala potensi bencana.

Komunikasi pada dasarnya merupakan kemampuan seseorang untuk memproduksi pesan secara tepat. Penjelasan tersebut memberikan sebuah gambaran bahwa dalam komunikasi terdapat pemberi pesan dan penerima pesan. Komunikasi juga dapat dianggap sebagai propses berbagi yang dapat merawat hubungan peserta komunikasi (Kincaid dan Schramm dalam Kamil, 2018). Komunikasi tidak hanya terjadi antara individu, akan tetapi komunikasi bisa terjadi antara kelompok dengan kelompok lainnya baik pemerintah maupun swasta. Komunikasi telah menjadi metode utama masyarakat dalam menyampaikan aspirasi kepada pemerintah, begutupun sebaliknya. Menurut Freire (dalam Idris, 2017) komunikasi sebagai proses dialog dan partisipasi, oleh sebab itu segala kepentingan pemerintah sangat dipengaruhi oleh komunikasi yang dilakukan untuk menterjemahkan segala tindakan kebijakan yang telah dipilih. Komunikasi yang baik tentu akan mempengaruhi kesesuaian tindakan dengan rencana yang telah disepakati sebelumnya.

\section{Sinergitas Komunikasi Pemerintah Kota Bontang Dengan Masyarakat dan Swasta Dalam Penanggulangan Bencana.}

Komitmen dan konsistensi pemerintah Kota Bontang dalam penanggulangan bencana tidak cukup jika hanya melibatkan masing-masing OPD yang terkait sebagaimana yang telah di jelaskan pada pembahasan sebalumnya, namun keterlibatan masyarakat dan swasta juga memiliki peran penting yang tidak dapat dikesampingkan untuk ikut serta dalam penanggulangan bencana di Kota Botang. Oleh sebab itu untuk memaksimalkan penanggulangan bencana pemerintah Kota bontang telah membangun komunikasi dengan masyarakat dan swasta dengan melalui pendekatan program, teritorial dan bisnis. Dengan intesitas komunikasi pemerintah dengan masyarakat dan swasta dalam melaksanakan penanggulangan bencana sehingga dapat menimbulkan kesadaran dan partisipasi seluruh pihak terkait (masyarakat dan swasta), dan kemudian mempermudah proses pelaksanaan program-program yang telah rencanakan oleh pemerintah Kota Bontang dalam penanggulangan bencana. Sala satu program inovasi pemerintah kota bontang dalam memitigasi bencana ialah Program Kali Bersih (PROKSIH). Program tersebut berfokus pada normalisasi dan merestorasi sungai di Kota Bontang, mengingat bahwa sungai merupakan 
bagian yang memiliki fungsi penting sebagai pengendali banjir yang sangat efektif, program PROKSIH telah di laksanakan sejak tahun 2018. Melalui PROKSIH pemerintah kota bontang mampu megurai dan memperkecil daerahdaerah titik rawan bencana dalam 2 tahun terakhir ini.

Komunikasi pemerintah kota bontang melalui pendekatan program telah mampu memberikan penyadaran masyarakat akan pentingnya menjaga kondisi sungai sehingga masyarakat bisa memberikan dukungan penuh terhdapat program-program mitigasi bencana. Perlu disampaikan juga bahwa dengan pola komunikasi pemerintah kepada masyatakat yang intens dan dukungan beberapa OPD terkait di Kota Bontang telah mampu memberikan pamahaman yang mendasar terhadap masyarakat bahwa penanggulangan bencana tidak hanya tanggung jawab pemerintah melainkan tanggung jawab semua pihak melalui partisipasi aktif sehingga dapat menciptakan Manusia Tangguh Bencana (MATANA).

Selain dari program PROKSIH sebagaimana yang telah dijelakan sebelumnya, dalam aspek pembangunan bahwa berdasarkan ketentuan kebijakan Izin Mendirikan Bangunan (IMB) baik masyarakat maupun swasta diwajibkan untuk terlerlebih dahulu berkomunikasi dengan BPBD Kota Bontang terkait rencana pembangunan yang akan dilakukan dan selanjutnya setelah mendapat rekomendasi dari BPBD Kota Bontang barulah kemudian pihak terkait dapat melakukan pembangunan,hal ini dimaksudkan agar bangunan yang dibangun oleh masyarakat maupun swasta dapat menyesuaikn kondisi teritorial di Kota Bontang yang memiliki potensi bencana banjir dan tanah lonsor, serta potensi kebakaran. Dengan pola komunikasi siklus pemerintah dengan masyarakat dan swasta sehingga dapat memberikan sebuah kondisi kota yang aman dan nyaman dari bencana.

Komunikasi pemerintah kota bontang dalam penanggulangan bencana juga dibangun atas pendekatan teritorial yang kemudian dapat menimbulkan kesadaran masyarakat secara terstruktur yang mampu menggerakkan masyarakat secara suka rela demi kabaikan bersama sehinggan pemerintah daerah kota bontang hanyalah menjadi komando dan koordinasi akan setiap kebijakan penanggulangan bencana, karena pada tahap pelaksanaannya masyarakat kota bontang terlibat aktif dan bahkan sala satu warga kota bontang telah menawarkan sebuah aplikasi online yang dapat di gunakan untuk menampung data central kebencanaan (mendukung inovasi posko induk data dan informasi) di Kota Bontang yang dapat diakses oleh seluruh masyarakat selama 24 jam, sehingga masyarakat dengan mudah dapat mengatahui potensi bencana yang ada disekitarnya.

Selain membangun komunikasi pemerintahan melalui pendekatan program dan teritorial, pemerintah kota bontang masih memiliki strategi komunikasi yang juga telah memberikan dampak signifikan terhadap penanggulangan bencana di kota bontang, komunikasi tersebut ialah komunikasi pemerintahan yang dibangun atas pendekatan bisnis (untung/rugi) dengan merangkul pihak swasta dan memberikan rekomendasi standar bangunan bagi setiap mas- yarakat yang akan melakukan pembangunan gedung usahan maupun gedung hunian (rumah tinggal). Sistem komunikasi ini memberikan dampak kesadaran kolektif penanggulang bencana antara mayarakat dan awasta. Keberhasilan komunikasi pemerintahan di kota bontang ini ditandai dengan keterlibatan paerusahan-perusahaan yang ada di Kota Bontang dalam meberikan dukungan fasilitas kepada BPBD Kota Bontang dalam penenggulangan bencana berupa Perahu karet dan ambulans laut mangingat bahwa wilayah bontang memiliki wilayah pesisir dan ada sebagai masyarakt yang tinggal bermukin di daerah yang hanya dapat diakses melalui jalur laut yaitu daerah selangan dan tihi-tihi yang berada di kelurahan bontang lestari. Bahkan sebelumnya sala satu perusahan di kota bontang telah memfasilitasi masyarakat selangan dan tihi-tihi dalam pelatihan Penanganan Pertama Pada Kecelakaan (P3K).

Komunikasi pemerintahan dengan pendekatan bisnis atau untu rugi dalam penanggulangan bencana membuat masyarakat dan swastauntuk berkomunikasi dengan BPBD untuk mempertimbangkan segala ketentuan yang terdapat dalam Peraturan Daerah Kota Bontang Nomor 13 Tahun 2011 Tentang Bangunan Gedung dan potensi bencana yang ada di Kota Bontang. Disinilah letak otoritas pemerintah dalam memadukan kebijakan dan potensi bencana yang menjadi aspek penting dalam membangun komunikasi antara masyarakat dan swasta dalam upaya penanggulang benacan di kota bontang melalui pendekatan bisnis (untung/rugi), karena pada dasarkan setiap pembangunan gedung (gedung usaha dan gedung tempat tinggal) yang dibangun oleh masyarakat maupun swasta menginginkan sebuah kepastian keamanan dan kenyamanan yang dapat menghindarkan dari kejadian bencana yang dapat menimbulkan kerugian material maupun non material.

Hal yang perlu juga untuk disampaikan dalam tulisan ini bahwa pada dasarnya konsep komunikasi pemerintahan Kota Bontang dalam penanggulangan bencana juga memiliki konsep pendekatan komunikasi enam (6) aktor di dalam mewujudkan Manusia Tanggung Bencana (MATANA) di Kota Bontang. Enam aktor tersebut terdiri dari pemerintah, media massa, masyarakat, Ormas/forum/LSM, dunia usaha, dan Ahli/pakar.

Meskipun dalam penelitian ini hanya memmfouskan pada komunikasi pemerintahan (internal dan eksternal) dan masyarakat serta awasta dalam penanggulangn bencana di Kota Bontang. Namun dalam temuan penelitian ini memberikan pahaman bahwa selain dari konsep komunikasi antara pemerintah, masyarakat dan swasta di Kota Bontang dalam penanggulangan bencana, juga memberikan isyarat bahwa komunikasi perlu ditingkatkan secara masif pada level media massa, ahli/pakar dan Ormas/Forum/LSM yang ada di kota Bontang. Hal ini dilakukan dalam rangka menyempurnakan bangunan komunikasi pemerintahan kota bontang dalam penanggulangan bencana yang selama ini masih berfokus pada tahap komunikasi pemerintahan dengan masyarakat dan swasta. Temuan ini sekaligus kritikan terhadap konsep sebelumnya yang menjadi landasan penulis dalam mengeksplorasi penanggulangan bencana dalam perspektif komunikasi pemerintahan, dimana komunikasi pemerintahan 
(internal dan eksternal), masyarakat, swasta.hal tesebut tidaklah cukup dan perlu direkonstruksi sehingga konsep komunikasi pemerintahan 6 aktor dapat menjadi landasan komunikasi pemerintahan kota bontang dalam penanggulangan bencana sehinggan substansi kata "Bencana Menjadi Urusan Bersama" yang selama ini di gaungkan BPBD Kota Bontang dapat dimaknai dengan secara holistik oleh seluruh pihak yang ada di Kota Bontang.

Banyak ahli telah berikhtiar mengartikan batasan tentang komunikasi antara penguasa (pemerintah) dengan rakyatnya sebagai bentuk komunikasi politik dalam pemerintahan (Blumler dan Kavanah, dalam Aminulloh, 2014). Komunikasi pemerintahan dilakukan juga dalam rangka menstabilkan kondisi internal dan eksterna dalam penyelenggaraan pemerintahan di daerah. Bagaimanapun organisasi pemerintahan tidak akan dapat melaksanakan fungsinya dan tidak akan dapat mengefisienkan dan mengefektifkan penggunaan sumber-sumbernya, dan pada akhirnya tidak akan dapat mencapai tujuannya tanpa komunikasi (Beach, dalam Silalahi 2004). Apapun yang disampaikandan dilakukan oleh aktor pemerintahan maka akan selalu ada pesan komunikasi yang berada dalam bingkai kepentingan publik dan sebagai komunikator akan bertanggungjawab terhadap apa yang disampaikantermasuk efek yang ditimbulkannya. Komunikasi pemerintahan yang dilakukan di internal maupun di eksternal akan selalu menimbulkna efek politik yang jika salah dipahami akan melahirkan berbagai penilaian yang tentu akan menghambat proses pelaksanaan penanggulangan bencana.

Ide, gagasan dan program penanggulangan bencana dikomunikasikan pemerintah kepadamasyarakat dalam rangka mencapai tujuan daerah (Hasan dalam Munandar dan Suherman, 2016). Paradigman komunikasi pemerintahan tidak hanya terjadi dalam satu arah, namun dalam pemerintahan yang modern komunikasi pemerintahah tidak hanya dapat dilakukan oleh pemerintah kepada masyarakat, namun begitupin sebaliknya dengan komunikasi pemerintahan yang baik dapat menimbulkan hubungan timbal balik dan mempermuda masyarakat untuk berpartisipasi langsung dengan segala kebijakan penanggulangan bencana yang akan dialakukan oleh pemerintah, komunikasi pemerintahan juga dapat mempermudah proses penentuan kebijkan pemerintah yang merepresentasikan seluruh kepentingan. Komunikasi pemerintahan memiliki ruang dan fungsi yang sangat luas bagi pemerintahan itu sendiri sehingga komunikasi pemerintahan juga menjadi bagian penting dalam penanggulangan bencana. Disamping itu menurut hemat penulis komunikasi pemerintahan merupakan salah satu faktor penentu manajemen pemerintah untuk mengemas gagasan, program penanggulangan bencana yang akan dilakukan bersama masyarakat dan swasta yang akan menimbulkan dampak kebaikan bersama dengan meminimalisir bencana. Sejalan dengan pemahaman tersebut Ernia (2020) juga membenarkan bahwa tata kelola bencana sangat bergatung pada komunikasi yang dapat membentuk intraksi secara terus menerus antara pamerintah, swata dan masyarakat agar dapat saling memahami substansi komunikasi.
Gagasan dan program penanggulangan bencana yang dikomunikasikan oleh pemerintahan Kota Bontang mampu membentuk satu kesatuan tindakan dalam penanggulangan bencana yang dilakukan bersama dengan masyarakat dan kelompok kepentingan lainnya. Komunikasi pemerintahan dalam penananggulangan bencana di Kota Bontang tentu bukanlah hal yang mudah mengingat bahwa dalam setiap kemunikasi pemerintahan selalu menimbulkan pemaknaan yang positif dan negatif bagi masyarakat maupun kelompok tertentu, dengan demikian Hasan (dalam Mustani dkk, 2019) memberikan empat faktor yang menjadi penting untuk di kuasai oleh komunikator atau pemerintah yaitu keterampilan, sikap, pengetahuan dan sistem sosial budaya. Penanggulangan bencana di daerah dapat dicapai apabila, komunikasi eksekutif pemerintah atau pejabat pemerintah dapat memengaruhi sikap (attitude), pemahaman (understanding), dan perilaku (behavior) birokrasi dan masyarakat. sehingga akan menimbulkan kesadaran bersama terkait pentinganya ikut serta dalam penannggulangan bencana.

Pesan yang disampaikan dan yang diterima melalui komunikasi bukan saja berupa informasi, melainkan juga penyebaran ide-ide (sharing ideas), instruksi (instruction), atau perasaan-perasaan (feelings) berhubungan dengan tindakan dan kebijakan pemerintah yang akan dilakukan dalam rangka penanggulangan bencana. Dengan demikian, tiap orang maupun kelompok yang terlibat dalam penyelenggaraan pemerintahan demokratis merupakan bagian dari proses komunikasi pemerintahan (Buluamang dan Handika, 2018), dengan demikian komunikasi pemerintahan sangat berpengaruh terhadap upaya penanggulangan bencana. Pencapaian keseragaman pemahaman dalam penanggulangan bencana di Kota Bontang tentu patut diberikan apresiasi, karena menurut Denzin dan Lincoln (dalam Rahman dan Sjoraida, 2017) Keberagaman pola konseptual/kognitif merupakan hasil dari lingkungan historis, cultural, dan personal yang digali secara terus-menerus akan menghambat proses komunikasi pemerintahn dalam penanggulangan bencana. Hal tersebut sesuai dengan kondisi di Indonesia bahwa \pm 440 suku bangsadan \pm 13.000 dialek (Lestari, 2019) . Oleh sebab itu komunikasi pemerintahan dalam penannggulangan bencana sengat erat hubungannya dalam hal menciptakan keseragaman tindakan dalam melakukan penanggulangan bencana agar dapat dicapai penanggulangan bencana yang terukur dengan baik.

Hasil penelitian Boku yang dikutip dalam tulisan Buluamang dan Handika (2018) menyatakan bahwa segala bentuk laju pelaksanaan program dan kebijakan (penanggulangan bencana) yang akan dilakukan pemerintah sangat dipengaruhi oleh sinergitas pemerintahan. Sinergitas akan terbangun apabila terdapat intraksi yang dilakukan dengan strategi komunikasi yang baik. Pendapat tersebut didukungan dengan pernyataan Mead pencetus teori interaksi simbolik (dalam Lestari, 2019) menyebutkan bahwa teori interaksi simbolik berfokus pada hakikat manusia sebagai makhluk sosial. Setiap individu pasti memerlukan orang lain. Interaksiterjadi karena adanya pertukaran simbol yang membentukmakna tertentu. Simbol dalam hal ini diartikan sebagai bahasadan/atau tulisan. Dengan demikian proses kom- 
unikasi pemerintahan diperlukan agar trjadi intraksi simbolik pemerintah, masyarakat dan swasta sehingga dapat saling melangkapi dalam mewujudkan kepantingan bersama. Dengan demikian komunikasi pemerintahan merupakan faktor utama dalam membangun kerja sama anatar masyarakat dan swasta dalam penanggulangan bencana.

Hal terpenting juga perlu diketahui bahwa seperti yang telah disinggung pada paragraf seblumnya bahwa komunikasi pemerintahan terbagi atas dua tipe yaitu, komunikasi internal dan komunikasi eksternal. Komunikasi internal adalah komunikasi yang bergerak kebawah berdasarkan hirarkis organisasi, dalam komunikasi tersebut terdapat pesan berupa intruksi jabatan atau tugas, cara kerja tugas, prosedur dan kebijakan, misi dan tujuan, dan umpan balik kepada pegawai, pemberian motivasi, memberika informasi tujuan organisasi yang akan dicapai. Sedangkan komunikasi eksternal yaitu alur komunikasi yang berasal dari bawah kepimpinan berupa laporan kinerja program dan kebijakan yang telah disepakati bersama (Harris; Katz \& Kahn; Huseman; Pace \& Faules dalam Buluamang dan Handika, 2018). Konstruksi pemikiran tersebut merupakan sistem komunikasi pemerintahan yang dapat mewujudkan satu kesatuan konsep tindakan yang dapat dilakukan dalam proses penanggulangan becana yang pada dasarnya memiliki tuntutan atas keserasian tindakan antara pemerintah, masyarakat dan swasta melalui komunikasi pemerintahan.

\section{KESIMPULAN}

Keberhasilan pemerintah kota Bontang dalam penanggulangan bencana tidak dapat dipisahkan dari komitmen dan konsistensi pemerintah dalam membangun komunikasi kepada masyarakat dan pihak swasta. Melalui komunikasi pemerintahan dengan pendekatan teritorial, program, dan bisnis menjadi aspek utama saat ini dalam menciptakan kesadaran kolektif masyarakat dalam mengatisipasi bencana di Kota Bontang. dengan demikian inovasi-inovasi baik dalam program, pemetaan potensi bencana telah mempermudah masyarakat dalam mengekses data dan informasi kencanaan melalui layanan sistem terpusat baik secara manual maupun virtual.

Meskipun saat ini komunikasi pemerintahan Kota Bontang dalam penanggulangan bencana tendensinya masi pada komunikasi pemerintah kepada masyarakat dan swasta dala, akan tetapi pemerintah kota bontang dalam melakukan penanggulangan bencana secara terus menerus melakukan penyempurnaan melalui peningkatan komunikasi pemerintahan dengan pendekatan enam (6) aktor dalam penanggulangan bencana yaitu pemerintah, media massa, masyarakat Ormas/Forum/Asosiasi/LSM. Terjalinnnya komunikasi antara enam aktor tersebut menjadi faktor kunci bagi Kota Bontang dalam mengurai bencanasecara kontinu. Hal tersebut juga menunjukan bahwa dalam mengatasi bencana perkotaan dalam perspektif komunikasi pemerintahan tidak hanya dilakukan antara pemerintah, masyarakat dan swasta. Namun komunikasi pemerintahan dalam penanggulangan Bencana perlu ditambahkan aspek komunikasi pemerintahan kepada media massa, Ormas/Foru-
m/Asosiasi/LSM dan ahli/pakar. Konsep komunikasi inilah yang kemudian masi terus dikembangkan oleh pemerintah Kota Bontang dalam meciptakan siklus komunikasi menuju Manusia Tangguh Bencana (MATANA).

\section{UCAPAN TERIMAKASIH}

1. Terima kasih kepada pemerintah Kota Bontang yang telah membantu dalam memberikan data dan informasi terkait penelitian ini.

2. Terima kasih kepada pihak Fakultas Ilmu Sosial dan Ilmu Politik Universitas Mulawarman yang telah mendanai program Penelitian ini.

\section{REFERENSI}

Aminulloh, Akhirul. (2014). Model Komunikasi, Sifat Arogansi dan Etika Komunikasi Pemerintah Menuju Pelayanan Publik Prima. Jurnal Ilmu Komunikasi, 12(2), 98-108.

Albris, Kristoffer et.al. (2020). Strengthening Governance for Disaster Prevention, The Enhancing Risk Management Capabilities Guidelines. International Journal of Disaster Risk Reduction, 47, 101647.

Buluamang, Yohanes Museng Ola dan Handika, Leope Pinnega. (2018). Komunikasi Pemerintahan Antar Perangkat Daerah Di Provinsi Nusa Tenggara Timur. Jurnal Penelitian Komunikasi, 21(1), 57-72

Creswell, John W. (2016). Reserarch Desaign: Pendekatan Metode Kualitatif, Kuantitatif, dan Campuran. Yogyakarta: Pustaka Pelajar.

Ernia, Jason. (2020). Is there an international disaster risk reduction regime, Does it matter. Progress in Disaster Science 7, 100098.

Faturahman, Burhanudin Mukhamad. (2018). Konseptualisasi Mitigasi Bencana Melalui Perspektif Kebijakan Publik. Publisia: Jurnal Ilmu Administrasi Publik, 3(2), 122-134.

Idris, Nahri. (2017). Mengkaji Ulang Pola Komunikasi Pemerintah Dalam Pemberdayaan Suku Anak Dalam Di Provinsi Jambi. Jurnal Penelitian Pers dan Komunikasi Pembangunan, 21(1), 37-48.

Kamil, Indriyati. (2018). Peran Komunikasi Pemerintahan Dalam Penanganan Lingkungan Kumuh. Mediator: Jurnal Komunikasi, 11(1), 129-139.

Kanji, Repaul and Agrawal, Rajat. (2020). Exploring the use of corporate social responsibility in building disaster resilience through sustainable development in India: An interpretive structural modelling approach. Progress in Disaster Science 6, 100089.

Lestari, Puji. (2019). Perspektif Komunikasi Bencana. Yogyakarta. PT. Kanisius.

Munandar, harris dan Suherman, Maman. (2016). Aktivitas Komunikasi Pemerintahan Ridwan Kamil di Media Sosial. Prosiding Hubungan Masyarakat, 2(1), 423-430.

Mustanir, Ahmad dkk. (2019). Peranan Camat Dan Komunikasi Pemerintahan Terhadap Perencanaan Pembangunan Di Kecamatan Malua Kabupaten Enrekang. Jurnal Ilmiah Clean Government, 2(2), 94-114.

Noveriyanti, Baharudin. (2018). E-Government Sebagai Layanan Komunikasi Pemerintah Kota Surabaya: Studi Kematangan E-Government Sebagai Layanan KomunikasiGovernment To Government, Government To Citizen,Government To Business. Profetik Jurnal Komunikasi, 11(1), $37-53$.

Peraturan Daerah Kota Bontang Nomor 13 Tahun 2011 Tentang Bangunan Gedung.

Rahman, Aulia dan Sjoraida, Diah Fatma. (2017). Strategi Komunikasi Pemerintah Kabupaten Subang Menyosialisasikan Gerakan pembangun- 
an Untuk Rakyat Infrastruktur Berkelanjutan. Jurnal Kajian Komunikasi, 5(2), 136-146.

Silalahi, Ulber, (2004). Komunikasi Pemerintahan Mengirim Dan Menerima Informasi Tugas Dan Informasi Publik. Jurnal Administrasi Publik, 3(1), 36-54.

Undang-Undang Nomor 24 Tahun 2007 Tentang Penanggulangan Bencana.

Conflict of Interest Statement: The authors declare that the research was conducted in the absence of any commercial or financial relationships that could be construed as a potential conflict of interest.

Copyright $\odot 2021$ Jumansyah, et.al.This is an open-access article distributed under the terms of the Creative Commons Attribution License (CC BY). The use, distribution or reproduction in other forums is permitted, provided the original author(s) and the copyright owner(s) are credited and that the original publication in this journal is cited, in accordance with accepted academic practice. No use, distribution or reproduction is permitted which does not comply with these terms 